\title{
CD8 Cell to Lymphocyte Ratio Measurement
}

National Cancer Institute

\section{Source}

National Cancer Institute. CD8 Cell to Lymphocyte Ratio Measurement. NCI Thesaurus.

Code C103816.

The determination of the ratio of CD8 cells compared to lymphocytes present in a sample. The measurement may be expressed as a ratio or percentage. 